In this connection it should be observed that it is a general rule that when a molecule adds on atoms to itself, the resultant aggregate of atoms usually exerts an intensity of molecular attraction less than that of the original molecule. For example, high-grade types of combination are nearly always more volatile than lower types of combination of the same molecular weight. Saturated compounds are more volatile than unsaturated compounds of the same molecular weight. Chemically unstable compounds are invariably more volatile than stable compounds of the same molecular weight, and the addition of atoms to a molecule decreases its stability.

The point is discussed fully in a paper which appeared in the Chemical Neres some time ago (vol. 1xxxix. p. 24I).

We should therefore expect to find that when a substance $A$ in a liquid combines with molecules of the liquid, the intensity of the molecular attraction which the new compound exerts would diminish as the number of molecules of the liquid added on to the molecule $\mathrm{A}$ increases.

When this is not the case, van 't Hoff's law cannot be obeyed at all closely by the dissolved substance.

Kiel, September 6.

Geoffrey Martin.

\section{THE ROYAL PHOTOGRAPHIC SOCIETY'S} ANNUAL EXHIBITION.

THIS exhibition will remain open until October 29. Although the scientific and technical section is disappointing, for, taken as a whole, it is below the standard of the last few years, there are several exhibits that are well worth attention. We are glad to notice an improvement in the arrangement, each department being kept more distinct than heretofore.

Zoological work is better represented than any other. Captain F. D. S. Fayrer shows several photographs of the daboia (a venomous viper), in one of which venom can be distinctly seen hanging from the fangs. As an example of photographic difficulties successfully overcome, the "Flying Sea Gull" of Mr. B. H. Bentley should be noticed. There are several sets of prints illustrating progressive changes. The one that will probably be considered the most notable is "A comparison of a jump of one foot in height as executed by a dog and a cat respectively." There are sixteen photographs of each animal showing as many stages of the jump, and they demonstrate that both animals judge with remarkable nicety the rise necessary to clear the obstacle, and that the movement of the legs is the same in both cases. "The Embryology of a Chicken," by Mr. W. M. Martin, is a series of seventy photographs, one by Röntgen rays, some by transmitted light, and some by a combination of transmitted and reflected light. It is clever and useful work which must have needed considerable patience for its execution. The Zoological Photographic Club has contributed a number of very interesting and meritorious photographs, including one by $\mathrm{Mr}$. Douglas English of the Orkney vole, the last discovered British mammal.

Mr. R. H. Baskett shows how, by means of a simple original such as a piece of lace or a sprig of forget-me-not or bramble, many designs may be obtained by the use of mirrors as in a kaleidoscope, if the multiplied image is photographed. He says that millions of designs may be obtained for the cost of the plates. A truly amateur's view of the matter in neglecting the cost of the apparatus and the time of the worker!

Colour photography is but poorly represented. A basket of fruit by Mr. S. R. Brewerton, done by the Sanger-Shepherd imbibition process, is a notable example, but such fine work has been done by this method that we cannot pass over the background, which if not unfortunate in its tint has not been reproduced with the perfection that we expect. Of the specimens of commercial colour work there is little to be said. What is wanted for exhibition is the original with its reproduction, produced without any fine etching or other hand work; then we shall be able to see what colour photography pure and simple is capable of, and to judge of its progress. If the trichromatic prints produced by Dr. Jumeaux's process fairly show the capabilities of that process, we can only say that it is a long way behind other processes. Photographers should notice the "three-colour carbon print " by Mr. J. Gilbert Jackson, as for obvious reasons they are not likely often to have the opportunity of seeing prints produced in this way. The carbon tissue is triply coated, so that the high lights show blue, the half tones, ochre, and the low tones, green. Of course, the colour in the print is in no way dependent on the colour of the object. The interest of the exhibit lies only in the fact that the method has been seriously proposed for practical work.

A telephotograph of St. Paul's showing a direct magnification of twenty-four diameters demonstrates excellently the usefulness of this kind of work. A number of photomicrographs, some Playertype enlargements, some star maps, and a few other items are all worth examination; but the most notable of the remaining exhibits is a series of radiographs showing bone diseases by Mr. C. Thurstan Holland The amount of detail obtained in difficult circumstances is remarkable, and the exhibit is further praiseworthy as forming a connected whole instead of, as we often see, a heterogeneous collection of examples that have happened to turn out well. We regret to notice that there is no apparatus whateve: in this section of the exhibition. Probably th presence of the trade exhibits in the central court is the reason for the disappearance of what used to be one of the main sections, but general exhibits by the trade do not take the place of a classified selection of new apparatus. In the central court will be found new cameras, or modifications of old ones, by several makers, and some new sensitometric apparatus and a recording chronograph by Messrs. SangerShepherd and Co., besides, of course, a large selection of the various specialities of the exhibitors.

Of lantern slides there is a fair number, and they appear to be of more than usual interest. A series by Dr. G. H. Rodman showing how by the use of Röntgen rays the structure of molluscan shells can be shown, and a series of studies in the biology of flowers by Mr. B. H. Bentley, are the most conspicuous. But we cannot discover when these can be seen properly displayed, for a slide is not made to be looked at, but to furnish an enlarged image on a sheet. It appears that at the lantern lectures, which are given at intervals, other slides are shown.

\section{PROF. N.R. FINSEN}

THERE are many records of patient heroism in the history of scientific investigation, but there are few careers in which strenuous work for the alleviation of human suffering has been carried on at greater disadvantage than that of the late Prof. Finsen, of Copenhagen.

Twenty years ago, he was the victim of a severe attack of rheumatism, which left the heart seriously damaged, and this was followed by disease of the liver and dropsy. By the greatest self-denial, and the most careful regulation of his dietary, Finsen 
lived on, in spite of his terrible affliction, devoted to his work, developing his theories, and putting them to practical use in the treatment of disease. For some time past he had been confined to his house, and could only direct the labours of others in the great Light Institute at Copenhagen. His death occurred on Saturday, September 24, at the early age of fortythree.

Niels R. Finsen was born in the Færoë Isles, and spent some of his earlier years in Iceland. After eight years' study at the University of Copenhagen, he was appointed lecturer on anatomy. But his attention was soon directed to the investigation of the influence of light on living organisms.

Starting from Widmark's observations on the inflammation of the skin caused by the ultra-violet rays of light, he developed in 1893 the red-light treatment of small-pox: The exclusion of the chemical rays by red curtains modifies the course of this disease, and diminishes scarring. A prolonged series of observations was then made on the influence of light upon various animals, proving that the chemical rays produce irritative and deleterious effects.

Later, Finsen investigated in a masterly manner the bactericidal power of the ultra-violet rays, a development of the work of Downes and Blunt. The practical application of these experimental researches was the treatment of lupus by light, an advance in therapeutics which has placed in the hands of the medical. profession a means of combating this intractable and most disfiguring disease.

Fortunately, Finsen's work was not allowed to languish for want of financial support. His friends helped him, and then the State aided him with a loan, free of interest, and the Light Institute was built. Since it was opened, -2000 patients have been treated.

The interest taken by Queen Alexandra in the work of her countryman led to the introduction of the light treatment into this country, and her gift of the apparatus to the London Hospital was followed by generous assistance from private donors enabling that institution to carry out the Finsen treatment with remarkable success.

Finsen was a man of noble qualities, of high scientific attainments, and of a remarkably inventive mind. The construction of his apparatus is sufficient to indicate this. It was no chance discovery, but was laboriously built up by the adaptation of scientific principles. His modesty, quiet humour, and total absence of self-seeking brought him the esteem and affection of all who knew him.

Always a poor man, Finsen could with difficulty be persuaded to retain for the use of his family any part of the Nobel prize of 100,000 crowns which was awarded him. He wanted to give all to his institute, but eventually agreed that half should be placed at interest for his family, to revert subsequently to his great "work. This institute and its benefrial cures are a fitting memorial of a splendid life of quiet heroism in the cause of science.

\section{NOTES.}

A CAREER of high promise was cut short by a lamentable accident at the "Devil's Kitchen," near Bethesda, North Wales; on September 2o. Mr. Ronald William Henry Turnbull Hudson, lecturer in mathematics at the University of Liverpool, who, with Mr. J. F. Cameron, lecturer of Caius College, Cambridge, was climbing a difficult couloir, dislodged a mass of rock; and, falling with it, was instantly killed Mr. Hudson, who was just twenty-eight years of NO. 1822 , VOL. 7O] age, was the son of Prof. W. H. H. Hudson, of King's College, London, and the brother of two sisters who recently distinguished themselves in mathematics at Newnham College. He was educated at St. Paul's School and St. John's College, Cambridge. He gained every college award that was open to him, and graduated as senior wrangler in 1898 , his friend $\mathrm{Mr}$. Cameron being second wrangler. The two comrades were alone in the first division of the first class in part ii. of the tripos in 1899 , and in the following year each was a Smith's prizeman. In Igoo Mr. Hudson was elected a fellow of his college, and engaged with success. in teaching and research. He graduated M.A. in igoz, and was appointed lecturer at Liverpool, where his powers. rapidly matured. He published a number of papers, chiefly on analytical and geometrical subjects, which manifested much freshness and skill, as well as width of interest and of kriowledge. He was unusually well read in classical and modern literature, and in experimental science. In athletic pursuits he was also keenly interested, and more than once steered his college boat to victory. It was confidently expected that ere long he would be promoted to a professorial chair, for which his gifts and acquirements specially fitted him. The news of his untimely death was received in Cambridge with the deepest regret, and with sincere sympathy for his family and college.

THE fifth annual Huxley memorial lecture of the Anthropological Institute will be delivered on Friday, October 7 , in the theatre of the Civil Service Commission, Burlington Gardens, when Dr. J. Deniker, of Paris, will lecture on the different racial elements in the present population of Europe.

THE King has conferred the title "Royal " upon the Edinburgh Museum of Science and Art, and approved its designation being altered to "The Royal Scottish Museum."

Extensions made to Millport Marine Biological Station, including new laboratory, research rooms, tank-room, and library, all the gift of Mr. James Coats, jun., of Paisley, were opened on Tuesday by Sir John Primrose, Lord Provost of Glasgow.

The Liverpool School of Tropical Medicine proposes to dispatch a second expedition to the Amazon in view of the necessity of further investigation of yellow fever. The expedition will probably start at the end of this year.

THE National Association for the Feeble-minded and the National Union of Special School Teachers have arranged a conference to be held at the Guildhall on October 13 and I4 to discuss various aspects of physically, mentally, and morally defective children.

ReuTER's correspondent at Naples states that the Vesuvius Observatory has issued the following notice:- "The activity of Vesuvius is very great. The walls of the crater, which have collapsed, tend to obstruct the bottom of the crater, whence proceed immense explosions and volcanic dust. The torrent of lava in the valley of Atrio del Cavallo is forming small volcanoes, the explosions from which attain a height of $1_{50}$ metres. Large fissures have occurred in the great cone, the rupture of which is considered possible." The eruption of Mount Vésuvius on September 23 is said to have been the greatest within the last ten years. On September 25 explosions were frequent, and masses of igneous matter were hurled to great heights. Parts of the neighbouring woods have been burned, the funicular railway has been damaged, and the guides" quarters have been destroyed. 